\title{
The ecclesiastical difficulty of Ephesians 4:1-6 in view of the different perspectives on the baptism in the Holy Spirit and the gifts of the Holy Spirit
}

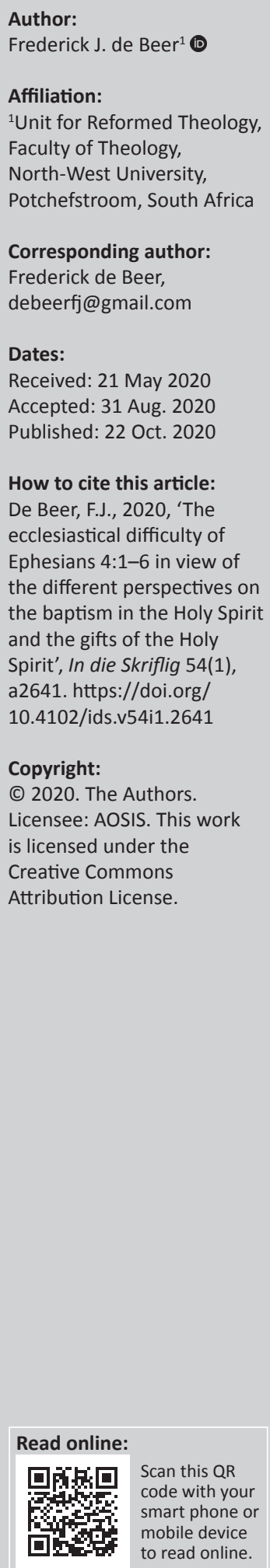

\begin{abstract}
Visible church unity, where believers from different theological traditions accept and regard one another as part of the invisible church, has always been a contentious issue. This article will address this issue by focusing specifically on the relationship between the Reformed and the Pentecostal tradition, being two of the major theological traditions, as it relates to contemporary Christianity and a post-Christian world. While attempting to create an awareness of the necessity that the Reformed and Pentecostal traditions need to re-evaluate their disposition towards one another, Paul's exhortation in Ephesians 4:1-6 is interpreted. The hypothesis of the article is that the Pentecostal and Reformed tradition should, without negating their respective theological traditions, consider Ephesians 4:1-6 as a possible measuring ethos in view of visible unity, to validate the witness of the church in a contemporary post-Christian world.
\end{abstract}

Keywords: church unity; Pentecostal; Reformed; Holy Spirit; tongues; gifts of the Spirit; cessationists; continuationists.

\section{Introduction}

Unity in the church has been a contentious issue for many decades with the visible church characterised by disunity (Kärkkäinen 2017:309). Apart from the numerous denominations, there are also numerous different theological traditions such as the Anglican/Episcopalian tradition, the Arminian, Wesleyan and Methodist tradition, the Baptist tradition, the Dispensational tradition, Lutheran tradition, the Reformed or Presbyterian tradition, and the Renewal/ Charismatic/Pentecostal tradition (Grudem 1994:6). The relation between the Reformed and the Pentecostal tradition ${ }^{1}$ has for decades been inauspicious, coupled with uncongenial opinions of each other, which is an unfortunate witness to the unity of the visible church. The doctrine of the Holy Spirit has caused numerous debates and controversy over the years between the Pentecostal and the Reformed traditions. Especially two aspects gave rise to serious disagreements, namely the interpretation and views on the baptism in the Holy Spirit and secondly, the question regarding the continuation of the charismatic gifts. In a contemporary world, where Christianity has lost its prerogative and relegated to 'just another religion' among many others, it is time for theological traditions, especially the Reformed and Pentecostal traditions, to reconsider their relationship with each other. Without necessarily renouncing or compromising their specific theological tradition, it must be argued that an intentional attempt to re-evaluate historic disposition must be considered, in view of the witness of the church in an ever-growing agnostic environment. While the writer comes from a Pentecostal tradition, the hypothesis of this article would infer that Ephesians 4:1-6 should be considered as a measuring ethos when speaking of visible unity between the Reformed and Pentecostal traditions. While continuing in their respective theological traditions, it will induce a more visible unity that will validate the witness of the church in a contemporary post-Christian world.

In Ephesians 4:3, Paul exhorts the church in Ephesus to 'make every effort to keep the unity of the Spirit through the bond of peace'. While Paul argues unity, a unity which was created by the presence and working of the Spirit, it seems that the interpretation and understanding of the presence and working of the Spirit by the Reformed and Pentecostal traditions created more division and strife than ecclesiastical tolerance or acceptance, while in essence both are part of the one, holy, catholic, apostolic church (Kärkkäinen 2017:430). This article will not address or 1.This article, in view of discoursing unity, chose to focus on two specific traditions, namely the Reformed and the Pentecostal traditions,
both of which are diverse within themselves. There is, nevertheless, reasonable consensus that the Reformed tradition is qualified as 'cessationists', while the Pentecostal and Charismatic tradition is qualified as 'continuationists' (Nel 2017:784). 
discourse the different interpretations of the Holy Spirit, or the interpretations pertaining to tongues, or the gifts of the Spirit between the two traditions in detail, as the scope of this article is Ephesians 4:1-6 as a possible measuring ethos for engagement, despite the different interpretations. It is nevertheless necessary to allude to the following:

Pentecostal traditions mostly hold that the initial evidence for the baptism in the Holy Spirit is the speaking in tongues, and that the charismatic spiritual gifts still manifest in the church and that it should be practised. This is also known as continuationism (Archer 2005:109; Burger 2017:100; Grudem 1994:683; Möller 1997:18; Wyckoff 1994:425). The baptism in the Holy Spirit is also interpreted as a subsequent event to conversion (Burger 2017:78; Macchia 2006:21; Möller 1997:24; Wyckoff 1994:427). While the expression 'baptism in the Spirit' does not appear in the Bible, it is the general terminology used by most Pentecostals while also using expressions such as 'being filled with the Holy Spirit' and 'receiving the Holy Spirit' (Nel 2016:170; Wyckoff 1994:425). Whatever terminology is however used, it is mostly with the interpretation that tongues are the initial sign and evidence for the baptism in the Holy Spirit (Burger 2017:85, 97). The Pentecostal understanding of the baptism in the Holy Spirit is mainly due to their Lukan perspective in Acts that describes the happenings on the day of Pentecost and the subsequent events after the day of Pentecost. This view does not necessarily distinguish between Lukan and Pauline pneumatology, but interprets Paul's letters according to Acts (Archer 2005:188; Nel 2017:788).

It needs to be mentioned that there are some underlining differences between Pentecostals, the charismatic movement, and neo-pentecostalism in so far as the practising and understanding of tongues and the gifts of the Spirit (Erickson 2001:282; Macchia 2006:26). Charismatics do not necessarily share the view that tongues are the initial sign of baptism in the Holy Spirit, or that the baptism in the Holy Spirit is a second, separate occurrence, as some Pentecostals do, but do, however, share the same view that all the spiritual gifts mentioned in the New Testament, must still be practised, and that tongues did not cease (Carson 1987:42; Grudem 1994:663; Macchia 2006:33). The scope of this article is, however, not the different views on tongues and the practising of the gifts in Pentecostal and Charismatic theology, and these will therefore not be addressed. The Pentecostal and the charismatic movements are nevertheless for the most part, grouped as the same theological tradition (Erickson 2001:282; König 2005:358), and for the purpose of this article, Pentecostals will to a greater extend also include the charismatic movement.

Opposed to the Pentecostal view of the baptism in the Holy Spirit, and the subsequent Pentecostal and charismatic views on the manifestation of the gifts of the Holy Spirit, are the views mostly associated with the Reformed tradition. These views argue that the outpouring of the Holy Spirit was a once and for all occurrence, and that, after the day of Pentecost, believers are filled by the Holy Spirit at conversion without any specific sign such as the speaking in tongues (Erickson 2001:282-284; 2013:820; MacArthur 1994:62). These views further maintain that the charismatic spiritual gifts were only needed to establish the church, and ceased thereafter, and are also known as the doctrine of cessationism² (Bavinck 2011:493; Geisler 2011:1181; König 2006:175; MacArthur 1984:454). Geisler (2001), claiming to be a 'moderate Calvinist', even argues that it was only the apostles that spoke in tongues (Geisler 2011:1563), although this view is not necessarily associated with the Reformed tradition.

These different understandings and interpretations regarding the Holy Spirit are therefore one of the major differences between the Pentecostal and the Reformed traditions (König 2005:357). Other differences are the views on water baptism and predestination, but the specific views on the Holy Spirit seem to have defined the identity and character of each other's particular approach in so far as liturgy and theological paradigms, be it Pentecostal or Reformed (Erickson 2013:800). These different views and interpretations of the Holy Spirit gave rise to the fact that the Reformed and Pentecostal traditions over time viewed one another contemptuously to some degree. The different interpretations resulted in a dissonance between these two traditions as illustrated in the following:

There are those from the Reformed tradition that label the Pentecostal movement as a flawed theology, that adapted an improper interpretation of God to suit their own agenda and perspectives. Pentecostals are furthermore accused of elevating the so-called experience of the Holy Spirit, above sound doctrine of the Holy Spirit, namely that their interpretation on speaking in tongues is based on an errant view of Spirit baptism and belittle the speaking in tongues as 'spiritual gibberish', which is also found among pagan religions (Carson 1987:12; Erickson 2013:800; Geisler 2011:1183; MacArthur 2013:16, 71, 72; Nel 2015:2; Van der Walt 2003:27-29). MacArthur (2013), who argues that many Pentecostals and charismatics 'created their own golden-calf version of the Holy Spirit', clearly exhibits some prejudice against the Pentecostal or charismatic movement when he states:

They have thrown their theology into the fires of human experience and worshipped the false spirit that came out - parading themselves before it with bizarre antics and unrestrained behaviour. As a movement, they have persistently ignored the truth about the Holy Spirit and with reckless license set up an idol spirit in the house of God, dishonouring the third member of the Trinity in His own name. (p. xiv)

Pentecostals, for their part, were also at times guilty of demonstrating some condemnatory attitudes against those that differed from their views. Pentecostals would label believers from the Reformed tradition as 'conservative traditionalists', who do not really believe in the Bible, who

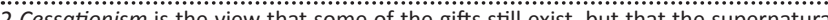
gifts have passed away, as these gifts were signs of an apostle and were only needed gifts have passed away, as these gifts were signs of an apostle and were only needed to establish the church, and were not given for the continuation of the church. Their purpose was only foundational and once the apostles passed away, the need for supernatural signs no longer exists (Geisler 2011:1181-1183). 
have no desire for God, lack spiritual power, cannot worship, and are too proud to humble themselves before God (Carson 1987:11). In South Africa the Reformed churches were accused of discriminating and opposing the Pentecostal movement, which resulted in the Pentecostal movement developing a resentment against anything associated with traditional and established churches, labelling them as formalistic and rigid (Burger 1987:306; Nel 2018a:5). Pentecostal Christians also questioned the sincerity of the Reformed Christians as being religious without an earnest spiritual relationship with God, spiritually dead, institutionalised, and ritualised. Pentecostals even entertained an attitude of superiority over other churches who did not experience the baptism in the Holy Spirit as to their interpretation thereof (Nel 2014:114; 2018b:2).

On the premise that Paul is the author of Ephesians (Bruce 1984:232; Fee 2007:363; Snodgrass 1996:23-29), Paul urges the church of Ephesus in Ephesians 4:1-6 to live a life worthy of their calling, be completely humble and gentle, be patient, bearing with one another in love and to make every effort to keep the unity of the Spirit through the bond of peace. This unity has its essence and foundation in the Spirit. The unity is the result of the presence of the Spirit, who created this unity and works in all Christians, baptising them into the same Christ. The unity that Paul is accentuating, was given by the Spirit and was not created or manufactured by the church (Snodgrass 1996:197; Stott 1979:152). With the 'now and the not yet', which is so unique to Paul's theology, unity is already present (Eph 4:4), while the Ephesians are exhorted to strive for the 'not yet' in Ephesians 4:13 'until we all reach unity' (Snodgrass 1996:198).

While there are various texts in the New Testament where unity is addressed, this article will focus on Ephesians 4:1-6 in view of examining it as a possible measuring ethos, when speaking of visible unity; and in its intended application, may contribute to validating the witness of the church in a contemporary post-Christian world.

\section{Evaluating Ephesians 4:1-6 in view of a possible measuring ethos}

As a prisoner for the Lord, then, I urge you to live a life worthy of the calling you have received. Be completely humble and gentle; be patient, bearing with one another in love. Make every effort to keep the unity of the Spirit through the bond of peace. There is one body and one Spirit, just as you were called to one hope when you were called; one Lord, one faith, one baptism; one God and Father of all, who is over all and through all and in all. (Eph 4:1-6 [New International Version \{NIV\}])

There is a general consensus that the letter to the Ephesians was not predominately an apostolic letter to a congregation in a specific geographical area, but was intended for a wider Christian community (Martin 1991:3-6; Snodgrass 1996:21). The first audience was the Jewish and Gentile believers who needed to hear that they were united and were reconciled into a new 'body' (Heil 2007:168; Slater 2012:5; Snodgrass 1996:23). In Ephesians 4:1-16, unity is generally regarded as the predominant theme, with Ephesians 4:1-6 as the exhortation in view of Ephesians 4:7-16, namely the church as the body of Christ, which is entrenched in diversity (Roberts 1993:102; Stott 1979:146). Ephesians 4:1-16 is one of the most descriptive passages to the church, and contains important and specific theological instructions where Paul, in his exhortation, moves from doctrine to responsibility and action, from indicative to imperative (Snodgrass 1996:194; Stott 1979:146; Swindoll 2015:526). Interpreting Ephesians 4:1-6 in view of our contemporary situations is comparatively easy to comprehend. Disunity is a well-known accusation against the church. The observation made by Snodgrass (1996:210), serves as a warning and accusation to the contemporary church when he says: 'we can hardly use Ephesians 4 as a description of the 20th-century church'.

\section{Paul's exhortation: Unity: A life worthy of the calling}

In verse one, $\pi \alpha \rho \alpha \kappa \alpha \lambda \tilde{\omega}$, a typical Pauline exhortation, Paul's instruction implies 'the state of having been called to a particular task', to live a Christian life that corresponds to the standards set by God (Larkin 2009:67; Louw \& Nida 1988:424, 628; Talbert 2007:108). This is the principle imperative, and the following four imperatives in verse two are all to be interpreted in view of the principal imperative, namely 'to live a life worthy of the calling you have received' (Larkin 2009:69; Snodgrass 1996:196). It can be argued that both Reformed and Pentecostal believers will aspire to this exhortation, to live a life worthy of God's calling. This is a life based on the Christ event and the confession that Christ died and rose from the dead. Pentecostals share the same confessions as Reformed believers, namely the triune God, and participate in the common confession of all churches and Christians (Kärkkäinen 2017:321). The calling is based on the Christ event and God's saving work as delineated by Paul in the first three chapters of Ephesians; if both traditions confess to this calling, it is a shared reciprocation.

\section{Characteristics of a life worthy of the calling}

Verse two specifies four imperatives, namely be completely humble, be gentle, be patient, and bearing with one another in love. These imperatives must serve the principle imperative in verse one. The first imperative, 'being completely humble' ( $\mu \varepsilon \tau \alpha \dot{\alpha} \pi \alpha ́ \sigma \eta \varsigma \tau \alpha \pi \varepsilon ı$ being a slave, and was not deemed a desired attribute; it was even regarded as a weakness (Slater 2012:106; Snodgrass 1996:19). Paul elevates this characteristic to be a significant attribute of one, living a life worthy of his or her calling, as an alternative to the normativity of arrogance that characterises human attitude. 'Being completely humble', the attitude of a slave, signifies a clear injunction of servanthood, which was the attitude of Christ, where religious arrogance and grandeur, as well as the misconception of spiritual snobbery is totally nullified.

Coupled with humbleness, is the second imperative - 'to

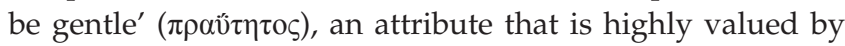


Paul and appears with regularity in his letters (Snodgrass 1996:196). Gentleness, the opposite of harshness, alludes to one's behaviour towards others. It can also in some instances be expressed in an idiomatic manner to imply 'always speaking softly to or not raising one's voice' (Louw \& Nida 1988:747). Being gentle with one another is an attribute ascribed to Christ in his behaviour towards sinful humanity while on earth. Gentleness therefore is the attitude of having consideration for others, with a willingness to relinquish one's rights (O'Brien 1999:278). It is this attribute that should be part of Christian behaviour when dealing with one another, with the humbleness to acknowledge that no tradition can claim to have an absolute interpretation of the Holy Spirit, thereby being gentle, or 'speaking softly and not raising one's voice'.

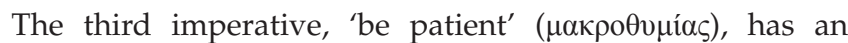
etymological meaning, namely 'to have a wide and big soul' (Snodgrass 1996:197) with $\mu \alpha \kappa \rho о \theta v \mu i ́ \alpha, \alpha \varsigma$, implying 'a state of emotional calm in the face of provocation' (Louw \& Nida 1988:307). While 'being humble, gentle and patient' were considered signs of weakness in Greco Roman society, these attributes became well-established virtues in early Christianity (Slater 2012:106). To be patient is both an Old and New Testament attribute, ascribed to the character of God in his patience with his people (O'Brien 1999:278). The 'not yet' of Ephesians 4:13, can only be realised if the imperative 'be patient' ( $\mu \alpha \kappa \rho o \theta v \mu i \alpha \varsigma)$ leads to a greater appreciation of each other, with the willingness to take a fresh look at the Bible that may lead to a greater understanding and tolerance of other viewpoints, and even greater doctrinal consensus in the church (Grudem 1994:6). Doctrinal consensus coming from patients, should also incorporate consent to disagree with one another, while still accepting one another as part of the body of Christ.

The fourth imperative, 'bearing with one another in love'

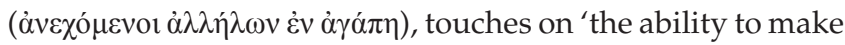
allowances for others' shortcomings and the tolerance of others exasperated behaviour' (Heil 2007:168). Snodgrass $(1996: 197)$ is of the opinion that the translation of the imperative, $\dot{\alpha} v \varepsilon \chi \delta ́ \mu \varepsilon v o เ \dot{\alpha} \lambda \lambda \eta \dot{\eta} \lambda \omega v \dot{\varepsilon} v \dot{\alpha} \gamma \alpha \dot{\pi} \eta$, as 'bearing with one another in love', is rather archaic and should instead be translated as 'putting up with each other in love'. While love has always been the greatest virtue that Paul communicated in his writings, he expounds on love in a peculiar way to the Ephesians, in that he encourages them to 'allow themselves to be imposed upon by other Christians and to do so as an act of love' (Slater 2012:107). Being 'imposed upon', is generally an unwelcome and unpleasant experience, but Paul is expecting the Ephesians to endure this in love. This imperative, nevertheless, petitions a willingness to accommodate one another on account of love, which does not imply agreement but acceptance. All who confess the Christ event, share the same identity in Christ, the mutual experience of Christ, and therefore the prescripts instructed by Christ (Snodgrass 1996:209). Both Reformed theology and Pentecostal theology are well-argued and established traditions based on the confessions of the Christ event. The imperative of this scripture would suggest that 'to put up with one another in love', is not the consequence of agreeing with one another, but regardless of not agreeing with one another.

\section{An earnest effort for unity}

It is only in the adherence to Ephesians 4:2 that the church can attempt to accomplish verse 3, starting with the phrase: 'eager to maintain' ( $\sigma \pi 0 v \delta$ ó an earnest effort by believers to achieve a specific outcome, namely the unity that was created by the Spirit and that the Spirit has given through the bond of peace. This unity, which is not the design or creation of the church (Snodgrass 1996:197; Stott 1979:152; Talbert 2007:108), can therefore never be treated as the prerogative of the church in deciding who is part of it and who is not, when those concerned are all bound by the confession of the Christ event. $\Sigma \pi$ ov $\delta$ á $\zeta \omega$ also implies 'to do something with intense effort and motivation, to work hard, to do one's best to endeavor' (Louw \& Nida 1988:662). 'To maintain' ( $\tau \eta \rho \tilde{i v})$, is a 'particular nuance' whereby a continuance 'state, condition or activity' is caused, namely 'of holding on to something so as not to give it up or lose it' (Larkin 2009:69) and 'to cause to continue, to retain, to keep' (Louw \& Nida 1988:153). The apprehension, acceptance, and acknowledgement of the unity, as an already established reality as a result of the working of the Spirit, should caution all believers when dealing with one another. The reality of this unity is that those who confess Christ, are already united in Christ, whether they confess that or not. This reminds of the words of Jesus when he addressed the issue of divorce in Mark 10:9: 'Therefore what God has joined together, let no one separate' (NIV).

Unity (غ่vó $\left.\eta_{\zeta}\right)$ is 'a state of oneness' (Louw \& Nida 1988:613),

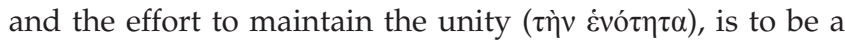
'persistent and consistent' purpose of every believer that confesses to being a member of the body of Christ (Swindoll

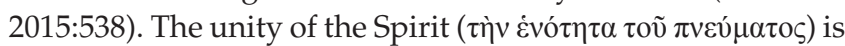
a unity brought about by the Spirit and does therefore not suggest merely a spirit of unity (Larkin 2009:70; Snodgrass 1996:197; Adams 1997:152). With the understanding of 'the now and the not yet' in Paul's theology, this unity already exists in the invisible church, the reality in God's perspective of only one church, and this unity is indestructible (Snodgrass 1996:198; Stott 1979:151). The unity in the visible church becomes a paradoxical quandary, and it appears that Paul was cognisant of this disposition between believers. Hence, his exhortation that a continuous effort must be made to maintain within the visible church, that which already exists in the invisible church: the unity of the Spirit. In the phrase,

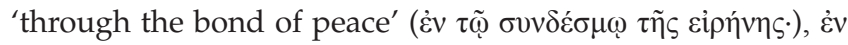
$\tau \tilde{\omega} \sigma v v \delta \delta \dot{\varepsilon} \sigma \mu \omega$ can be interpreted as either the activity of the readers, or that of the Spirit with the noun referring to 'that which brings various entities into a unified relationship' (Larkin 2009:70). It can hardly be imagined that the Spirit will be guilty of not maintaining the unity 'through the bond of peace'. Christ is the author of peace which is the result of the 
Christ event. The church is therefore exhorted to embrace this peace, as Christ has called the church into peace (Slater 2012:107; Swindoll 2015:279). The primary imperative, supported by the following imperatives, serves as the structure in order to sustain the unity brought about by the Spirit, regardless of differences and are in effect summed up with the statement made by Meldenius (as cited in Snodgrass 1996:211): 'Unity in essentials, liberty in incidentals and in all things charity [love]'.

Unity is furthermore accentuated by using 'one' in Ephesians 4:4-6, emphasising the foundational importance of unity as a gift from Christ (Snodgrass 1996:198). 'One' is used sevenfold, and each time accentuates some aspect of unity, namely one body ( $\tilde{\varepsilon} v \sigma \tilde{\omega} \mu \alpha)$, one Spirit ( $\tilde{\varepsilon} v \pi v \varepsilon v \tilde{\mu} \alpha)$, one

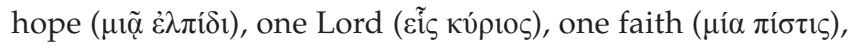
one baptism ( $\tilde{v} \vee \beta \alpha ́ \pi \tau 1 \sigma \mu \alpha)$, and one God and Father of all

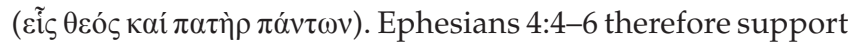
the preceding exhortation in graphic and inspiring language (Larkin 2009:70; Slater 2012:169; Snodgrass 1996:198; Talbert 2007:109).

\section{'One body' as the expression of unity}

'One body' in Ephesians 4:4, immediate reminds of Paul's other exhortation to the church in 1 Corinthians 12, when dealing with the gifts of the Spirit. While there are different gifts and different kinds of service, there is only one body (1 Cor 12:12). Paul, the only New Testament writer that uses the body image (Snodgrass 1996:198), counsels the church that just as the different parts of the body cannot say to one another 'I don't need you', so too can the church not say 'I do not need you', being one body (1 Cor 12:21). This is echoed by Grudem (1994) who says:

But it certainly is not helpful to the church as a whole for both sides to think they can learn nothing from the other, or that they can gain no benefit from fellowship with each other. (p. 1046)

The body $(\sigma \omega \mu \alpha)$ is a subject of diversity, as only a small part of the body is similar; yet, in its diversity, it forms an essential unity and can only materialise in the embracement of its indispensable diversity. The Corinthians, who mistook uniformity and similarity with unity, were compelled by Paul to embrace diversity, and so is Paul's exhortation to the Ephesians, by using the image of a body (Fee 2007:388).

\section{Unity accentuated by 'one'}

One Spirit ( $\tilde{\varepsilon} v \pi v \varepsilon \tilde{v} \mu \alpha)$, one hope ( $\mu 1 \tilde{\alpha} \dot{\varepsilon} \lambda \pi i \delta \imath)$, one Lord

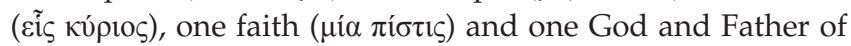

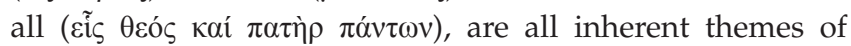
corporate, organisational and spiritual unity (Slater 2012:107). These are all theological affirmations to which both traditions confess. While these affirmations underline the unity, they also allude to the Trinity and the believer's relationship with the Trinity. The normal order of confessions, when referring to the Trinity, is 'Father, Son, and Spirit', while the order in Ephesians is Spirit, Lord (Son), and then Father. The order of the Trinity in Ephesians 4:4-6 is only to serve the immediate context of Paul's exhortation to maintain the unity that the Spirit created. 'Lord' was a favourite acclimation for Jesus in Paul's letters, and while 'Lord' was the title for Yahweh in the Old Testament, 'Lord' in Ephesians 4:4 undoubtedly refers to Jesus (O'Brien 1999:280-283). This is therefore not an attempt from Paul to emphasise the Spirit at the expense of the Father. These affirmations are all more reason why Reformed and Pentecostal believers must 'make every effort to keep the unity of the Spirit through the bond of peace'.

\section{Baptism: One or more?}

The affirmation 'one baptism' ( $\tilde{v} \vee \beta \alpha ́ \pi \tau 1 \sigma \mu \alpha$ ) might be the only contentious affirmation in the acclamation of Paul's exhortation, that may cause further debate between Reformed and Pentecostal traditions in contemporary Christianity. The issues surrounding baptism have caused serious division for many decades, not only between the Reformed and Pentecostal tradition, but even within the Reformed tradition (Brown 2014:176). It can, however, be argued that it is no longer the devastating dividing factor in contemporary Christianity, as it has been in the past. The different interpretations are still part of Reformed, baptist and Pentecostal theology, but if all believers can come to a mutual agreement that baptism is not the major doctrine of the faith, visible unity is possible, if they are willing to live with each other's views. The two major issues pertaining to baptism that will always be debated are the recipients of baptism, and the mode of baptism. In order to find common ground between the Reformed and Pentecostal tradition, Paul's exhortation of 'bearing with one another in love' and to 'make every effort to keep the unity of the Spirit through the bond of peace' should, however, guide believers in understanding the meaning and significance of baptism that each tradition appreciates. While disagreeing with one another on some aspects of baptism, there should be the acknowledgement of some common ground when it is understood that baptism points everyone to Jesus Christ (Armstrong 2007:125-128; Grudem 1994:863-864; König 2006:125). Believers are baptised into one body by one Spirit (1 Cor 12:13) and the Spirit imparts unity to all that were baptised (Bruce 1984:334; O’Brien 1999:281). While the mode and specific theology of baptism may differ, there remains one common denominator, the Reformed and Pentecostal believer's identification with Christ (Swindoll 2015:277), which should be enough to adhere to Paul's exhortation to 'make every effort to keep the unity of the Spirit through the bond of peace'.

\section{One God: For and in all}

In the phrase, 'one God and Father of all, who is over all and

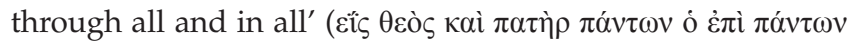

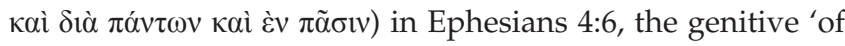
all' signify both Jew and Gentile, while the adjective clause 'one God and Father', describes God as 'transcendent, pervasive and immanent' in all (Bruce 1984:337). This is significant in view of the first readers, who were Jews and Gentiles, unified into one body. So are all believers now also, 
unified by the Spirit in Christ when confessing Christ and the Christ event (Swindoll 2015:278) and therefore Reformed and Pentecostal believers are also united in one body.

\section{Hope for unity in contemporary Christianity}

While the letter to the Ephesians was addressed to the church in Ephesus, it is also understood as a letter to the church and believers right up to this day (Snodgrass 1996:18-20). The unity of the Spirit does not imply an organisational structural or denominational unity, as correctly argued by MacArthur (1986:202). It, nevertheless, entertains a visible component in that there should be a mutual acceptance and recognition of each other as fellow believers. While MacArthur correctly interprets Ephesians 4:3 as the 'inner and universal unity of the Spirit by which every true believer is bound to every other true believer', he regrettably excludes the Pentecostal believer, as he contends that Pentecostals and charismatics do not belong to the true church, hence his reason for writing a book against the Pentecostal and charismatic movement (MacArthur 2013:248).

While there, to a certain extent, still remains some distance between the Pentecostal and Reformed traditions, there seems to be a genuine and sincere attempt to bridge these differences with an openness towards one other, without necessarily abandoning a specific theological interpretation of the baptism in the Holy Spirit, or views on the gifts of the Holy Spirit. This is evident in the continuous ReformedPentecostal dialogue with the latest hosted by the Asia Pacific Theological Seminary on 23-30 October 2019 (Tanis 2019). The agreement between the Apostolic Faith Mission (AFM) of South Africa, as a Pentecostal church, with the North-West University and Faculty of Theology of the North-West University (Nel \& Janse van Rensburg 2016:7-10), is also an indication of a growing willingness to engage regardless of theological differences. The Faculty of Theology of the NorthWest University now accommodates both Pentecostal and Reformed paradigms as part of the curriculums.

In contemporary Christianity, there are many who are undecided on these issues, and some that contend that these issues cannot be decided from the Bible (Grudem 1994:1031). Contemporary Christianity may even be defined according to a predicament describe by Carson (1987:215), who pastored an assembly whose membership comprised of some 'procharismatics', some 'anticharismatics', and with the 'majority fairly confused between the two'. Carson, as a non-Pentecostal, strenuously object to the interpretation that speaking in tongues is the evidence of the baptism in the Spirit. He, nevertheless, concedes that the Pentecostal and charismatic movement has been a blessing to the church. While pointing out some questionable elements in the Pentecostal and charismatic movement, he contends that the Pentecostal tradition has challenged the church to expect more from God, and argue that non-pentecostals need to question a theology that rejects all possibility of the miraculous (Carson 1987:197, 209).
Pentecostals are aware of all the accusations and allegations levelled against them. These include unscriptural and erroneous Bible interpretations by some, such as the prosperity gospel, the need for a 'theology of suffering' (Keener 2017:227, 287-290; Adams 2019:536) and an awareness of the unhealthy authoritarian leadership styles of many pastors and leaders (Yong 2020:166). Contrary to the accusation that Pentecostals are not Christ centred, or that they have replaced the authority of the Bible with experience (MacArthur 2013:16, 42), Pentecostals are mindful that any new revelation, or any revelation for that matter, outside the norm of the Bible, will inevitably lead to subjectivism and fanaticism (Nel 2015:2).

It is therefore encouraging, that there are an appeal and an urgency for greater acceptance and recognition of each other, despite theological differences (Burger 2017:96; Grudem 1994:1046; Kärkkäinen 2017:421; Snodgrass 1996:210). This does not imply negating theological positions and has never meant cancelling out denominational markers (Kärkkäinen 2017:425). There is, however, a need for the Pentecostal and the Reformed tradition to come to a greater realising of their need for each other, because the Pentecostal movement tends to have more practical experience in the use of spiritual gifts, from which the Reformed tradition could benefit from, while the Reformed tradition has a rich understanding of Christian doctrine and the Bible, from which the Pentecostal tradition could also learn a lot from (Grudem 1994:1046).

\section{Conclusion}

Attempts to argue church unity, focus mainly on unity within specific denominations or theological traditions such as unity within the Apostolic Faith Mission of SA (Burger \& Nel 2008a:436; 2008b:113; Kgatle 2017:1-10), the Apostolic Faith Mission in Zimbabwe (Chivasa 2018:1-10), the Nederduitse Gereformeerde (Dutch Reformed) 'family' of churches (Bosch 1982:22), or the Reformed tradition who have since 1958 continuously deliberated on issues of disagreement in view of unity, but with no success (Coetzee 2006:163). The difficulty in church unity, even among churches from the same theological tradition, is amplified by the remarks made by Coetzee (2006):

We experience the disunity between churches, religious groups and ecumenical movements from different theological traditions. We, however, also experience the lack of real unity between church communities in the same Reformed tradition. (p. 164)

The harshness and sense of superiority that sometimes manifests when theological traditions defend their positions, bade not well to the witness of unity. Snodgrass (1996) rightly comments that:

Denominations and movements are as guilty of egotism and arrogance as individuals. Nearly all denominations have been guilty of arrogance and parochialism and have succumbed to fights that ignore the gospel. (p. 210)

Ephesians 4:1-6, as a possible measuring ethos of conduct between churches and theological traditions, would suggest 
caution in how believers would view and treat one another, while still maintaining different theological positions, especially on views pertaining to the Holy Spirit. The observation by Reformed theologian, Bavinck (2011:598), on the unity in Ephesians 4:1-6 that: 'In this oneness the Spirit does not undo but rather maintains and confirms the diversity that exists among believers', would be very meaningful, if that includes the diversity between theological traditions. It is therefore imperative that the Reformed and Pentecostal traditions re-evaluate their disposition towards one another, in view of visible unity in order to validate the witness of the church in contemporary Christianity and a post-Christian world. The starting point will be to accept the sincerity of each other, in their attempts to honestly deal with the Bible.

The confession made by the Lausanne Movement (The Cape Town Commitment) that:

We lament the dividedness and divisiveness of our churches and organizations. We deeply and urgently long for Christians to cultivate a spirit of grace and to be obedient to Paul's command [to] make every effort to maintain the unity of the Spirit in the bond of peace. (Kärkkäinen 2017:425)

This must serve as a reminder to all believers, and for that matter, the Reformed and Pentecostal believes of Paul's exhortation in Ephesians 4:1-6. Disunity, division and animosity between theological traditions have become 'the scandal of divided Christendom' to such an extent that 'it has become intolerable for the faith consciousness of countless modern Christians' (Kärkkäinen 2017:421).

\section{Acknowledgements \\ Competing interests}

The author declares that no competing interest exists.

\section{Author's contributions}

I declare that I am the sole author of this research article.

\section{Funding information}

This research received no specific grant from any funding agency in the public, commercial, or not-for-profit sectors.

\section{Ethical consideration}

This article followed all ethical standards for carrying out research.

\section{Data availability statement}

Data sharing is not applicable to this article as no new data were created or analysed in this study.

\section{Disclaimer}

The views and opinions expressed in this article are those of the author and do not necessarily reflect the official policy or position of any affiliated agency of the authors.

\section{References}

Adams, S., 2019, 'Book review, Pamela F. Engelbert, Who is present in absence? A pentecostal theological praxis of suffering and healing', Pneuma 41(1), 535-537.

Archer, K.J., 2005, A Pentecostal hermeneutic, CPT Press, Cleveland, TN.

Armstrong, J.H., 2007, 'Finding common ground amid disagreement and agreement', in P.E. Engle (ed.), Understanding four views on baptism, counterpoints series, pp. 125-148, Zondervan, Grand Rapids, MI.

Bavinck, H., 2011, Reformed dogmatics, in J. Bolt (ed.), Baker Academic, Grand Rapids, MI.

Bosch, D.J., 1982, 'Church unity amidst cultural diversity', Missionalia: Southern African Journal of Mission Studies 10(1), 16-28.

Brown, M.L., 2014, Authentic fire, Excel Publishers, Kerala.

Bruce, F.F., 1984, The epistles to the Colossians, to Philemon, and to the Ephesians, Eerdmans, Grand Rapids, MI.

Burger, I., 1987, Die Geskiedenis van die Apostoliese Geloof Sending van Suid Afrika, Evangelie Uitgewers, Braamfontein.

Burger, I., 2017, In Gees en in Waarheid, Christelike Uitgewersmaatskappy, Vereeniging.

Burger, I. \& Nel, M., 2008a, The Apostolic Faith Mission of South Africa 1908-2008, The AFM of SA, Centurion.

Burger, I. \& Nel, M., 2008b, The fire falls in Africa, Christian Art Publishers, Vereeniging.

Carson, D.A., 1987, Showing the spirit: A theological exposition of 1 Corinthians 12-14, Baker Book House, Grand Rapids, MI.

Chivasa, N., 2018, 'Instituting dispute resolution procedures in the Apostolic Faith Mission in Zimbabwe church', In die Skriflig 52(1), a2285. https://doi.org/10.4102/ ids.v52i1.2285

Coetzee, C.F.C., 2006, 'Christian identity and church unity', In die Skriflig 40(1), 155-168. https://doi.org/10.4102/ids.v40i1.337

Erickson, M.J., 2001, Introducing Christian doctrine, Baker Academic, Grand Rapids, MI.

Erickson, M.J., 2013, Christian theology, Baker Academic, Grand Rapids, MI.

Fee, G.D., 2007, Pauline Christology, Hendrickson Publishers, Peabody, MA.

Geisler, N.L., 2001, Chosen but free, Bethany House Publishers, Bloomington, MN.

Geisler, N.L., 2011, Systematic theology in one volume, Bethany House Publishers, MN.

Grudem, W., 1994, Systematic theology: An introduction to biblical doctrine, InterVarsity Press, Nottingham.

Heil, J.P., 2007, Ephesians: Empowerment to walk in love for the unity of all in Christ, Society of Biblical Literature, Atlanta, GA.

Kärkkäinen, V., 2017, Hope and community: A constructive Christian theology for the pluralistic world, vol. 5, Eerdmans, Grand Rapids, MI.

Keener, C.S., 2017, 'Refining spirit hermeneutics', Pneuma 39(1), 198-240. https://doi. org/10.1163/15700747-03901011

Kgatle, M.S., 2017, 'A socio-historical analysis of the sections in the Apostolic Faith Mission of South Africa from 1908 to the present', Verbum et Ecclesia 38(1), a1668. https://doi.org/10.4102/ve.v38i1.1668

König, A., 2005, Wat is reg? Weet iemand dalk? Lux Verbi, Wellington.

König, A., 2006, Die groot geloofswoordeboek, Christelike Uitgewersmaatskappy, Vereeniging.

Larkin, W., 2009, 'Ephesians', in M.M. Culy (ed.), Baylor handbook on the Greek New Testament, pp. 67-72, Baylor University Press, Waco, TX.

Louw, J.P. \& Nida, E.A., 1988, Greek-English lexicon of the New Testament based on semantic domains, United Bible Societies, New York, NY

MacArthur, J., 1984, 'First Corinthians' in MacArthur New Testament commentary, pp. 453-468, Moody Press Chicago, II.

MacArthur, J., 1986, Ephesians: The MacArthur New Testament commentary, Moody Press, Chicago, IL.

MacArthur, J., 1994, Acts 1-12: The MacArthur New Testament commentary, Moody Press, Chicago, IL.

MacArthur, J., 2013, Strange fire, Nelson Books, Nashville, TN.

Macchia, F.D., 2006, Baptized in the Spirit, Zondervan, Michigan, MI.

Nel, M., 2017, 'Pentecostals and the pulpit: A case study of the Apostolic Faith Mission of South Africa', HTS Teologiese Studies/Theological Studies 74(2), 4664. https:// doi.org/10.4102/hts.v74i2.4664

Nel, M., 2018b, 'Pentecostal ecumenical impulses: Past and present challenges', In die Skriflig 52(1), a2330. https://doi.org/10.4102/ids.v52i1.2330

Nel, M. \& Janse van Rensburg, F., 2016, 'Integrating spirituality and rationality the long and arduous journey of the historical development of theological training in the Apostolic Faith Mission of South Africa, In die Skriflig 50(2), a1943. https://doi.
org/10.4102/ids.v50i2.1943

O'Brien, P.T., 1999, 'The letter to the Ephesians', in D.A. Carson (ed.), The Pillar New Testament Commentary, pp. 271-286, Eerdmans, Grand Rapids, MI.

Roberts, J.H., 1993, 'The enigma of Ephesians: Rethinking some positions on the basis of Schnackenburg and Arnold', Neotestamentica 27(1), 93-106.

Slater, T.B., 2012, 'Ephesians', in R. Scott Nash (ed.), Smyth \& Helwys Bible Commentary, pp. 105-109, Smyth \& Helwys Publishing, Macon, GA. 
Snodgrass, K., 1996, 'Ephesians', in T. Muck (ed.), The NIV application commentary, pp. 193-227, Zondervan, Grand Rapids, MI.

Stott, R.W., 1979, 'The message of Ephesians', in J.A. Motyer \& J.R.W. Stott (eds.), The Bible speaks today, pp. 145-155, InterVarsity, Press, Leister.

Swindoll, C.R., 2015, 'Galatians, Ephesians', Swindoll's living insights New Testamen commentary, pp. 526-545, Tyndale House Publishers, Carol Stream, IL.

Talbert, C.H., 2007, 'Ephesians and Colossians', in M.C. Parsons \& C.H. Talbert (eds.) Paideia commentaries on the New Testament, pp. 107-119, Baker Academic, Grand Rapids, MI.
Tanis, P., 2019, Reformed-Pentecostal dialogue distilling five years of discussion, World Communion of Reformed Churches, November 02, viewed 22 August 2020, from https://wcrc.ch/news/reformed-pentecostal-dialogue-distilling-five-years-of-discussion.

Van der Walt, J., 2003, 'Die gawe van tale ...: 'n Persoonlike ondervinding in Pinkstergeledere', Die Kerkblad 106(3158), 26-29.

Wyckoff, J.W., 1994, 'The baptism in the Holy Spirit', in S.M. Horton (ed.), Systematic theology: A Pentecostal perspective, pp. 423-455, Gospel Publishing House, Springfield, MO.

Yong, A., 2020, 'Book review, Vincent W. Lloyd, in Defense of Charisma', Pneuma 42(1), 107-167. https://doi.org/10.1163/15700747-04201022 